\title{
To study the factors effecting sales of leading tractor brands in Haryana (India)
}

\author{
Rajesh K Sharma ${ }^{1}$, Pardeep Kaur ${ }^{2}$ \\ ${ }^{I}$ (Department of Management, Vinayaka Mission University, Salem, India) \\ ${ }^{2}$ (Department of Management, Vinayaka Mission University, Salem, India)
}

\begin{abstract}
Abstarct : Every aspect of the economic life in India is influenced by the agriculture. Agriculture contributes nearly $32 \%$ of the national income of India and it offers live hood nearly $70 \%$ of the total population and the agriculture is influenced by the tractors industry. Tractor industry plays an important role on the development of agriculture. Indian tractor market is very complex so marketer must care in analysing consumer behaviour. Green Revolution in India had its origin in northern India where Haryana is situated. Thus Haryana's Contribution to Green Revolution in India is the maximum, In 1966-67 production of food grains in Haryana was 2090 thousand tones. In 1970-71 it increased to 3939 thousand tones and in 1994-2000 it further rose to 131 lakh tones, all this due to the development of tractor manufacturing industries like FARMTRAC, HMT, EICHER, TAFE etc. Present work covers studying sales of different tractor brands in Haryana (India) and how various brands have become the choice of agriculturist on the basis of getting experienced by others. The best brand so for is found to be FARMTRAC by agriculturist by the recommendation of relatives who have experinecd the same. It was depicted from the studies that farmers purchasing tractors by recommendations of relatives are not much educated.
\end{abstract}

Keywords - Tractor, Tractor brands, Tractor Industry, Tractor sales, Tractor sales sources

\section{INTRODUCTION}

Tractor machinery plays an important role in India's GDP. This agricultural machinery, the tractors came to India through imports but later on were successfully manufactured with foreign collaborations. The manufacturing process started in year 1961-62. Indian industry of tractor is relatively juvenile but now has become the prime market worldwide. On analyzing it was found that the penetration level of tractor is low as compared to world standards. The recent years study showed that the industry has registered a great sale in terms of domestic and even export. Northern region has become saturated in sale of new tractors like FARMTRAC, HMT, EICHER and TAFE but southern part is still penetrating. The horse power ranging 31-40 $\mathrm{HP}$ is most popular in north India and is considered as fastest elevating segment. The tractor industry increases per capital productivity of people and thus elevates living standard. Tractor industry volume in India in 1998 - 99 was 2, 54, 858 Horsepower forms the base of segmentation of said market. The segmentation ratio for less than $30 \mathrm{HP}, 31-40 \mathrm{HP}$ and more than $41 \mathrm{HP}$ is found to be 22.2:58.3:19.5. EICHER is the one of the leader in less than $30 \mathrm{HP}$ segment with a market share of $35.1 \%$. In the $31-40$ segments there is TAFE \& M\&M are leader each with the similar share of market of $25.7 \%$. Escorts and FARMTRAC has combined share of market of $37.7 \%$. . Indian tractor industry has grown at a phenomenon of pace during the last two decades to a record production of poor 10700 Nos by 1988-89 consequent. It occupies a place of eminence in the automobile industry of the Country. Besides, India has emerged as one of the leading producers of the tractor in the World. The current level of production of tractor in India is only surpassed by USA \& USSR 25 Years ago, Our Knowledge of complex farm machinery like tractors was extremely limited.

2.1 Aim of the research:

\section{Research Methodology}

- To identify purchase of particular brands of tractors between HMT, EICHER, TAFE, FARMTRAC.

- To examine Income and education level of respondents (customers) for purchasing own tractor attributed in the tractor brands of their choice.

- To identify the source of information which influence the buying decisions of the farmers for different tractors (HMT, EICHER, TAFE, FARMTRAC)

\subsection{Scope of study:}

The research would be helpful to control variances among different tractor brands. It would be helpful to formulate research design in tractor industry. It would be helpful in determining consumer behavior towards tractors. These factors are essential because every aspect of the economic life in India is influenced by the 
agriculture. Agriculture contributes nearly $32 \%$ of the national income of India and it offers live hood nearly $70 \%$ of the total population and the agriculture is influenced by the tractors industry. Tractor industry plays an important role on the development of agriculture

\subsection{Selection of Sample}

The field of sales and marketing being very vast makes it impossible to contact each and every individual of the population due to limitations of essential resources like time and money. Therefore, the study is preferably narrowed down to a representative sample to make the study more manageable. Keeping in view the objectives and resource limitations of the study a sample of 50 respondents were considered. The selected sample is representative of the total population and is accurate and practicable. A sample of 50 respondents of Ambala district has been selected at random of all those people who bought HMT, EICHER, TAFE, and FARMTRAC.

\subsection{Research Instruments}

A research instrument was the questionnaire. The Questionnaire was formulated in the simple language having most of the question in the close end form with multiple choices. However few open end questions were also included to get the originality of the answers in the responder's style.

The questionnaire divided in to two parts: -

Basic information

Identification of information about the brands

III. Data analysis and interpretation

Table1. Buying preferences for different brands of tractor

\begin{tabular}{|c|c|c|}
\hline Tractor Brand & No. of Respondents & Percentage (\%) \\
\hline HMT & 15 & 30 \\
\hline TAFE & 05 & 10 \\
\hline EICHER & 05 & 10 \\
\hline FARMTRAC & 25 & 50 \\
\hline
\end{tabular}

Table2. Income level of respondents for purchasing own tractor

\begin{tabular}{|c|c|c|}
\hline Annually Income (Rs.) & No. of Respondents & Percentage (\%) \\
\hline Up to $1,00,000$ & 33 & 66 \\
\hline $1,00,000$ to $1,50,000$ & 15 & 30 \\
\hline Up to $1,50,000$ & 02 & 04 \\
\hline
\end{tabular}

Table3: recommendations source to respondent for purchasing tractor brand

\begin{tabular}{|c|c|c|}
\hline Source Of Recommendation & Number of Farmers & Percentage (\%) \\
\hline Radio & 01 & 02 \\
\hline Relatives & 20 & 40 \\
\hline Dealer & 09 & 18 \\
\hline Neighbour & 09 & 18 \\
\hline Friends & 04 & 08 \\
\hline T.V. & 03 & 04 \\
\hline News paper & 05 & 10 \\
\hline
\end{tabular}

Table 4: Analysis of education level or agriculturists

\begin{tabular}{|c|c|c|}
\hline Education & Number of Respondents & Percentage \\
\hline Illiterate & 9 & 78 \\
\hline Up to Metric & 36 & 10 \\
\hline Graduate & 5 & Nil \\
\hline Post Graduate & Nil & 100 \\
\hline Total & 50 & \\
\hline
\end{tabular}

From the above data it is clears that the purchase attitudes of respondents are more towards FARMTRAC and HMT tractor brands. The above analysis indicates TAFE and EICHER brands are equally liked by consumers. So most of the farmers are using FARMTRAC but HMT tractor is more popular among farmers because their old goodwill and low maintenance. Income of the respondents determines their capacity to buy as well as the 
status of consumer. The respondents were further classified on the basis of the annual income. The study depicts that only low percentage of the respondents fall under the income category getting income 150001 to 200000 . This also implies that maximum purchasing of tractors is done by the respondents were getting income up to1, 00000. This depicts that the farmers are financial having good income and related to medium family. The Table 3 displays different sources, which influenced the purchase decision for the brands of tractors, selected for study. Relative have been deserved as most important source of recommendation for the purchase of the tractor. The TV and Radio advertisements are less important moreover dealers and neighbors are playing a role better than friends and news papers to influence the respondents. Here the study of above data draws conclusion that $40 \%$ of respondent influenced by relatives because in India people are blind believe on their relatives. None of the respondents is postgraduate. Most of the respondents are up to metric and some farmers are illiterate and some are graduates.

\section{Conclusion}

The given report analyses the current scenario of tractor industry in Haryana (India), discussing the type of tractor brand leading in said area and what source made this brand leader over others. It was found FARMTRAC is mostly liked by people from said place. From the study it becomes evident that most of the people take decision regarding the purchase of particular brand of tractor at their own besides, relatives are an important source of recommendation while company executive have little role in choosing a particulars brand of tractors. Nearly $50 \%$ of the studied farmers prefer to buy the FARMTRAC brand tractors, while the TAFE and EICHER are chosen only buy less number of farmers. Yet the income level is low still they prefer to purchase FARMTRAC tractors

\section{Recommendations}

Dealer should improve their operations they should explain the usage and maintenance of the tractor to every customer in a crystal clear manner. For the above purpose and to improve company image the minds of customer's company dealer/salesman should visit the existing customers of tractor.

\section{Bibliography}

[1] Kotler, P; Marketing Management (New Delhi, Prentice Hall of India)

[2] Gupta, S.P; Statistical Methods (Sultan Chand and Sons Publishers, 1984)

[3] Sherlekar, S.A; Marketing Management (Himalaya Publishing House 1984)

[4] Kotler, Philips \& Armstrong Marketing Management (New Delhi-Prentice Hall of India Private Limited 1995)

[5] Ramaswamy VS \& Namakumari S, Marketing Management- Planning, Implementation and Control, Second Edition (Macmillan India Limited, 1998) 